\title{
Analysis of Genetic Diversity of Ferns of Western Ghats in Mudigere region of Karnataka based on ISSR Markers
}

\author{
Vidyashree $^{1 *}$, S.Y. Chandrashekar ${ }^{1}$, D.C. Lakshmana $\operatorname{Reddy}^{2}$ and Lavanya Reddy ${ }^{2}$ \\ ${ }^{1}$ Department of Floriculture and Landscape Architecture, College of Horticulture, Mudigere, \\ Karnataka, India \\ ${ }^{2}$ Division of Biotechnology, Indian Institute of Horticulture Research, \\ Bengaluru, Karnataka, India
}

*Corresponding author

\begin{tabular}{|c|c|}
\hline & A B S T R A C T \\
\hline & \multirow{4}{*}{$\begin{array}{l}\text { In view of the high level of morphological diversity in fern species, assessment of genetic } \\
\text { variation among } 19 \text { fern species was evaluated using ten inter simple sequence repeat } \\
\text { (ISSR) markers. The results suggested that the ISSR markers produced much better } \\
\text { reproducible bands and were more efficient in grouping fern species. ISSR fragments } \\
\text { generated } 29 \text { to } 87 \text { bands per primer. A total of } 281 \text { polymorphic bands generated } 34.48 \text { to } \\
66.66 \text { per cent polymorphism per primer. All germplasm were clearly differentiated by } \\
\text { their ISSR fingerprints. The similarity coefficient on ISSR profiles were subjected to } \\
\text { UPGMA cluster analysis between the species was within the range from } 1.00 \text { to } 25 \text { per } \\
\text { cent. The dendrogram generated by ISSR markers revealed two major clusters, indicating } \\
\text { that fern species have distributed based on frond shape, frond type, type of rhizome, } \\
\text { habitat, stipe colour, texture, sori position. This is the first report in ferns genetic diversity } \\
\text { estimation and clustering by using ISSRs. }\end{array}$} \\
\hline $\begin{array}{l}\text { Ferns, Molecular } \\
\text { markers, Cluster } \\
\text { analysis, ISSR, } \\
\text { Dendrogram }\end{array}$ & \\
\hline Article Info & \\
\hline $\begin{array}{l}\text { Accepted: } \\
\text { 12 January } 2019 \\
\text { Available Online: } \\
\text { 10 February } 2019\end{array}$ & \\
\hline
\end{tabular}

\section{Introduction}

Ferns are homosporous, leptosporangic, pteridophytes, seedless, flowerless and oldest lineage of vascular plants (Oloyede (2012). Where, the ornamental use of ferns has been practiced since long time, but is now one of the important cut foliage in many countries around the world. The foliage of fern is highly valued in the international florist greenery market because of its long post-harvest life, low cost, year round availability and versatile design qualities in form, texture and colour
(Safeena, 2013). Due to ornamental nature of the fronds of Dryopteris, Adiantum, Nephrolepis, the potted plants of these species find place in the terrace of houses, hotels, gardens, etc. (Dixit, 2000).

The Western Ghats of peninsular India is of great phyto-geographical importance which constitutes one of the 34 global biodiversity hotspot centres, on account of exceptional levels of plant endemism because of its diversified topography and varied climatic conditions. Recently Fraser Jenkins (2012) 
reviewed pteridophytic numbers to be 1000 species in India. Western Himalaya and Western Ghats supported 399 and 349 pteridophytes species of fern and fern allies in India, respectively. In Central Western Ghats, Karnataka region houses richest pteridophytic diversity. About 26 species of Pteridophytes are listed in the forests around Mudigere taluk, in Chikkamagaluru district of Central Western Ghats (Parashurama et al., 2016). Apart from its aesthetic purpose, ferns are helpful to mankind in various ways. It is used as medicine in treating various diseases, majority of them are edible, some of them used as feed to animals because of their nutritive value and low levels of oxalate and cyanide. The medicinal uses of some ferns and pteridophytes of India have also been described (Caius, 1935; Nair, 1959). The medicinal uses of 61 different ferns and fern allies have been well documented earlier (Benjamin and Manickam, 2007). The ferns have also shown an important role in bioremediation of waste water ( $\mathrm{Ma}$ et al., 2001) found the Chinese Bracken fern namely Pteris vittata L. to be a hyper-accumulator of the toxic Arsenic metal.

Since time immemorial morphological traits have been used to estimate systematic relationships in crops and ornamentals. The prime advantages of morphological markers include they are simple, fast and inexpensive. Though simple and widely used, these descriptors suffer many drawbacks, such as influence of environment on trait expression, epistatic interaction and pleiotropic effects. Furthermore, paucity of sufficient number of stable morphological markers for unequivocal identification of increasing number of reference collection of varieties enforces to look for alternatives. The DNA markers have proved valuable in crop breeding, especially in studies on genetic diversity and gene mapping. Commonly used molecular markers like Restriction Fragment Length Polymorphisms (RFLPs), Random Amplified
Polymorphic DNA (RAPD), Amplified Fragment Length Polymorphisms (AFLPs), Sequence-Related Amplified Polymorphisms (SRAPs), Simple Sequence Repeats (SSRs) and Inter-Simple Sequence Repeats (ISSRs) which provide excellent tools to study the genetic diversity. The major limitations of these methods are low reproducibility of RAPD, high cost of AFLP and the need to know the flanking sequences to develop species specific primers for SSR polymorphism.

ISSR markers were used to relate genetic distinction within the selected species. Knowledge of the genetic diversity of existing germplasm can informatively guide parental selection in breeding improvement programs. Presently, many Fern species are described in India, but little research has been done on genetic diversity. Thus, planning a specific strategy for its species identification in spite its variation stands as a credential task undeniably. Also, the superior genotype of the species was identified so that the conservation of the species made easy with special initiative.

\section{Materials and Methods}

\section{DNA isolation}

Genomic DNA was extracted from 19 fern species from fresh young leaves by modified CTAB method as described by Doyle and Doyle (1987). The quality and quantity of isolated DNA samples were tested by agarose gel electrophoresis and the concentration of the DNA samples were determined using UVSpectrophotometer at the optical density of $260 \mathrm{~nm}$ and $280 \mathrm{~nm}$; the DNA samples were diluted to $40 \mathrm{ng} / \mu 1$ for PCR amplification.

\section{ISSR amplification}

ISSR amplification reactions were carried out in $25-\mu \mathrm{l}$ volume reaction mixture containing 
template DNA $400 \mathrm{ng} / \mu \mathrm{l}(2.5 \mu \mathrm{l}), \mathrm{Taq}$ polymerase $3 \mathrm{U} / \mu \mathrm{l}(0.5 \mu \mathrm{l})$, dNTP mix $(2.5$ $\mu \mathrm{l}), 20 \mathrm{pmol} / \mu \mathrm{l}$ primer $(2.0 \mu \mathrm{l})$ in $10 \mathrm{x}$ PCR Reaction buffer $(2.5 \mu \mathrm{l}), 20 \mathrm{mM} \mathrm{MgCl}_{2}(2.2$ $\mu \mathrm{l})$ and MilliQ water $(12.8 \mu \mathrm{l})$. Amplifications were performed in an Eppendorf Master Cycler gradient. Amplification conditions were one cycle at $95^{\circ} \mathrm{C}$ for $5 \mathrm{~min}$, and $94^{\circ} \mathrm{C}$ for $1 \mathrm{~min}, 54^{\circ} \mathrm{C}$ for $45 \mathrm{~s}$, followed by stepwise reduction of $1^{\circ} \mathrm{C}$ for the first five cycles, and $72^{\circ} \mathrm{C}$ for $2 \mathrm{~min}$. In subsequent 35 cycles, annealing temperature was maintained at $54^{\circ} \mathrm{C}$, followed by one cycle of $8 \mathrm{~min}$ at $72^{\circ} \mathrm{C}$. Amplified products were loaded on 1.5 $\%$ agarose and separated in $1 \times$ TAE buffer at $70 \mathrm{~V}$. The gels were visualized under UV after staining with ethidium bromide and the scoring was done by software UVTech1D. The primers used for the ISSR analysis are listed out in Table 1.

\section{Data analysis}

The gels from ISSR analysis were visualized and scoring was done at gel documentation system (UVTech1D). Scoring of bands was done on the basis of their presence (' 1 ') or absence ('0') in the gel. (Echt et al., 1992) and pair wise similarity matrix between species was calculated using NTSYS packages. The resulting similarity matrix was used to construct a dendrogram by means of the UPGMA (unweighted pair-group method using averages).

\section{Results and Discussion}

\section{ISSR analysis}

Analysis of 19 fern species revealed 281 polymorphic bands. Seventy four primer combinations were analyzed of which ten primers generated reproducible, informative and easily scorable ISSR profiles (Fig. 1). A total of 524 bands were scored, out of which 281 were polymorphic bands and the number of bands ranged from 29 to 87 per primer (Table 1). Similar results were found in Liu et al., 2007 in Adiantum reniformae var sinense, Lalitha et al., (2014a) in chrysanthemum, Lalitha et al., (2014b) in tuberose and Rashmi et al., (2015) in gladiolus.

\section{Cluster analysis}

The similarity matrix coefficient ranged from 1.00 to 25 per cent (Table 2), suggesting a low to high genetic variation within fern species. The highest genetic similarity of 25 per cent was observed between Pyrrosia porosa T. Moore and Aleuritopteris anceps (Blanf.) Panigrahi Presl followed by Pityrogramma calomelanos (L.) Link. and Cyathea nilgirensis Holttum had 10.40 per cent genetic similarity. While, Blechnum orientale L. had least genetic similarity index of 1.00 per cent. This could have happened due to highly heterozygous nature of this crop similar results were observed by and Perrie et $a l .$, (2003) in New Zealand fern and Kumar et al., 2016 in Gladiolous

All species were grouped into two major clusters. Within major group, there were further sub-clusters (Fig. 1). The first major cluster constituted fifteen species. The second major cluster constituted four species. The major cluster $\mathrm{I}$ in dendrogram is further divided into three sub clusters. Sub cluster I consists of Thelypteris (Christella) dentata (Forssk) and Diplazium esculentum (Retz.) Sw having oblong monomorphic fronds. Sub cluster II again sub divided into three groups; Group I, Group II and Group III. Group I again sub divided into three sub groups. Subgroup I includes three species Odontosoria tenuifolia (Lam.) J.Sm. (terminal sori), Pteris pellucida C. Presl. and Angiopteris helferiana C. Presl both have erect rhizome. While, Subgroup II include single species Parahemionitis cordata (Fraser-Jenk) having cordate frond. 
Table.1 ISSR primers used for diversity analysis

\begin{tabular}{|l|l|l|c|c|c|}
\hline $\begin{array}{l}\text { Sl. } \\
\text { No. }\end{array}$ & $\begin{array}{c}\text { Name of } \\
\text { the } \\
\text { primer }\end{array}$ & \multicolumn{1}{|c|}{ Primer sequence (3'-5') } & $\begin{array}{c}\text { No. of } \\
\text { polymorphic } \\
\text { bands }\end{array}$ & $\begin{array}{c}\text { No. of } \\
\text { Bands } \\
\text { produced }\end{array}$ & $\begin{array}{c}\text { Percentage } \\
\text { polymorphism }\end{array}$ \\
\hline $\mathbf{1}$ & ISSR 816 & 5'CACACACACACACACAT3' & 15 & 37 & 40.54 \\
\hline $\mathbf{2}$ & ISSR 845 & 5'CTCTCTCTCTCTCTCTCTRG3' & 10 & 29 & 34.48 \\
\hline $\mathbf{3}$ & ISSR 847 & 5'CACACACACACACACARC3' & 29 & 60 & 48.33 \\
\hline $\mathbf{4}$ & ISSR 851 & 5'GTGTGTGTGTGTGTGTYG3' & 12 & 30 & 40.00 \\
\hline $\mathbf{5}$ & ISSR 855 & 5'ACACACACACACACACYT3' & 20 & 43 & 46.51 \\
\hline $\mathbf{6}$ & ISSR 857 & 5'ACACACACACACACACYG3' & 11 & 30 & 36.40 \\
\hline $\mathbf{7}$ & ISSR 859 & 5'TGTGTGTGTGTGTGTGRTRC3' & 58 & 87 & 66.66 \\
\hline $\mathbf{8}$ & ISSR 861 & 5'ACCACCACCACCACCACC3' & 47 & 76 & 61.84 \\
\hline $\mathbf{9}$ & ISSR 862 & 5'ACCACCACCACCACCACC3' & 50 & 85 & 58.82 \\
\hline $\mathbf{1 0}$ & ISSR 888 & 5'BDBCACACACACACACA3' & 29 & 47 & 54.40 \\
\hline & Total & & $\mathbf{2 8 1}$ & $\mathbf{5 2 4}$ & \multirow{4}{*}{ ''A8.79 } \\
\hline & Mean & & $\mathbf{2 8 . 1}$ & $\mathbf{5 2 . 4}$ & \\
\hline
\end{tabular}

Table.2 Similarity co-efficient of fern species by using ISSR marker

\begin{tabular}{|c|c|c|c|c|c|c|c|c|c|c|c|c|c|c|c|c|c|c|c|}
\hline @ & 1 & 2 & 3 & 4 & 5 & 6 & 7 & 8 & 9 & 10 & 11 & 12 & 13 & 14 & 15 & 16 & 17 & 18 & 19 \\
\hline 1 & 1.00 & & & & & & & & & & & & & & & & & & \\
\hline 2 & 0.00 & 1.00 & & & & & & & & & & & & & & & & & \\
\hline 3 & 0.00 & 0.03 & 1.00 & & & & & & & & & & & & & & & & \\
\hline 4 & 0.00 & 0.00 & 0.00 & 1.00 & & & & & & & & & & & & & & & \\
\hline 5 & 0.00 & 0.00 & 0.00 & 0.25 & 1.00 & & & & & & & & & & & & & & \\
\hline 6 & 0.04 & 0.06 & 0.05 & 0.01 & 0.01 & 1.00 & & & & & & & & & & & & & \\
\hline 7 & 0.00 & 0.00 & 0.00 & 0.09 & 0.00 & 0.00 & 1.00 & & & & & & & & & & & & \\
\hline 8 & 0.00 & 0.01 & 0.01 & 0.03 & 0.03 & 0.04 & 0.00 & 1.00 & & & & & & & & & & & \\
\hline 9 & 0.03 & 0.04 & 0.05 & 0.00 & 0.02 & 0.02 & 0.00 & 0.03 & 1.00 & & & & & & & & & & \\
\hline 10 & 0.04 & 0.04 & 0.05 & 0.03 & 0.03 & 0.03 & 0.03 & 0.02 & 0.03 & 1.00 & & & & & & & & & \\
\hline 11 & 0.01 & 0.03 & 0.07 & 0.00 & 0.00 & 0.09 & 0.00 & 0.00 & 0.03 & 0.03 & 1.00 & & & & & & & & \\
\hline 12 & 0.03 & 0.04 & 0.03 & 0.00 & 0.00 & 0.05 & 0.00 & 0.01 & 0.02 & 0.03 & 0.02 & 1.00 & & & & & & & \\
\hline 13 & 0.00 & 0.00 & 0.00 & 0.00 & 0.00 & 0.01 & 0.09 & 0.03 & 0.00 & 0.00 & 0.02 & 0.04 & 1.00 & & & & & & \\
\hline 14 & 0.01 & 0.04 & 0.02 & 0.00 & 0.00 & 0.06 & 0.00 & 0.03 & 0.03 & 0.01 & 0.05 & 0.02 & 0.08 & 1.00 & & & & & \\
\hline 15 & 0.01 & 0.06 & 0.05 & 0.00 & 0.00 & 0.09 & 0.00 & 0.01 & 0.01 & 0.01 & 0.06 & 0.06 & 0.00 & 0.04 & 1.00 & & & & \\
\hline 16 & 0.05 & 0.05 & 0.04 & 0.00 & 0.00 & 0.04 & 0.00 & 0.07 & 0.02 & 0.03 & 0.03 & 0.05 & 0.02 & 0.03 & 0.03 & 1.00 & & & \\
\hline 17 & 0.04 & 0.03 & 0.03 & 0.00 & 0.00 & 0.03 & 0.00 & 0.04 & 0.02 & 0.38 & 0.10 & 0.06 & 0.02 & 0.03 & 0.02 & 0.02 & 1.00 & & \\
\hline 18 & 0.03 & 0.00 & 0.00 & 0.00 & 0.00 & 0.00 & 0.00 & 0.02 & 0.00 & 0.00 & 0.00 & 0.02 & 0.00 & 0.00 & 0.00 & 0.00 & 0.03 & 1.00 & \\
\hline 19 & 0.00 & 0.01 & 0.02 & 0.00 & 0.00 & 0.03 & 0.00 & 0.03 & 0.06 & 0.06 & 0.05 & 0.01 & 0.00 & 0.01 & 0.01 & 0.01 & 0.01 & 0.25 & 1.00 \\
\hline
\end{tabular}


Fig.1 Dendrogram showing genetic relationship among 19 fern species based on ISSR markers according to unweighted pair group method with arithmetic average (UPGMA) analysis

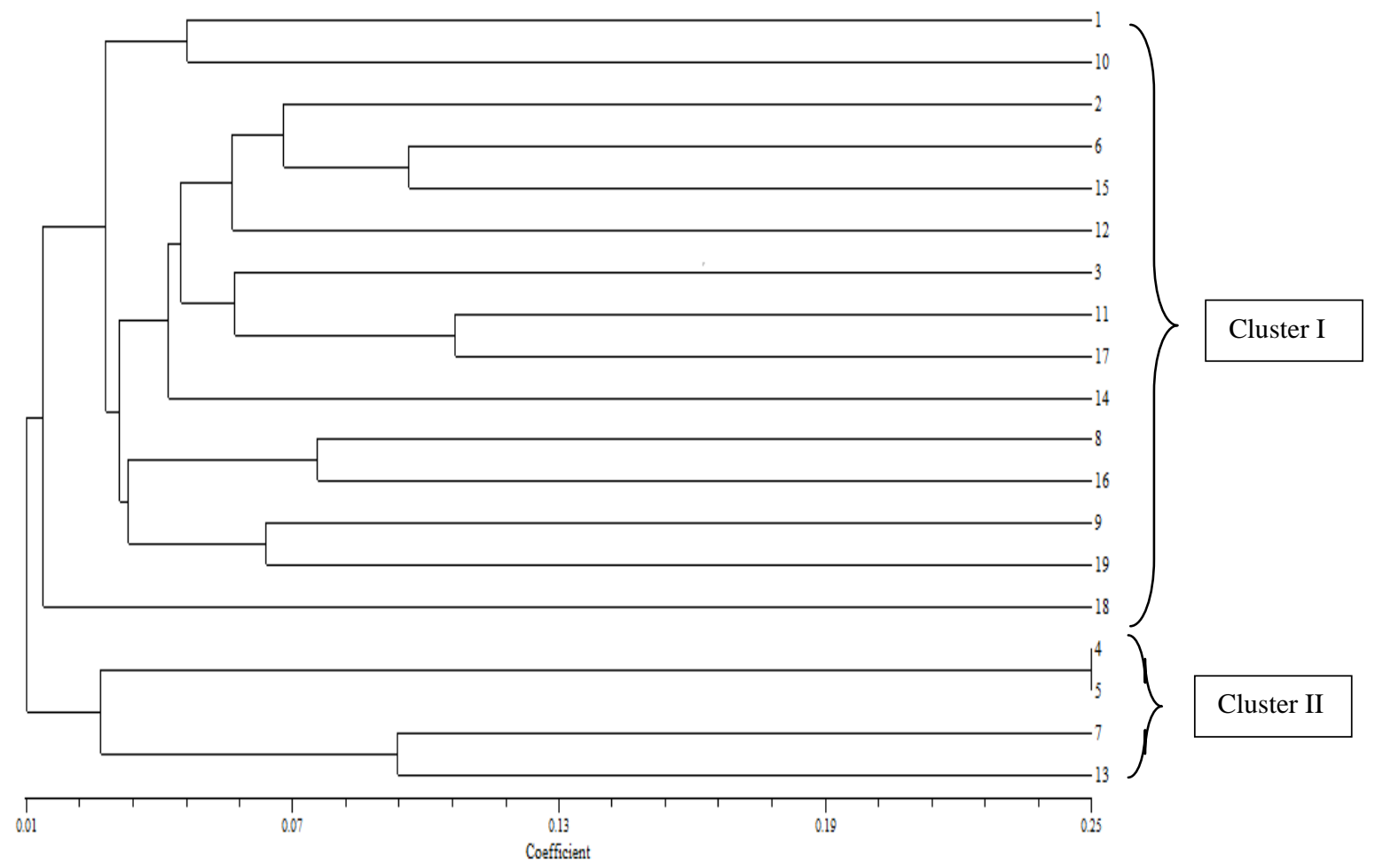

1. Thelypteris (Christella) dentata (Forssk)

2. Odontosoria tenuifolia (Lam.) J.Sm.

3. Asplenium obscurum Bl.

4. Pyrrosia porosa T. Moore

5. Aleuritopteris anceps (Blanf.) Panigrahi

6. Pteris pellucida C. Presl.

7. Bolbitis semicordata (Bak.) Ching.
8. Tectaria paradoxa (Wallich. ex Hook.)

9. Dryopteris cochleata (Buch. Ham. ex D. Don) 16. Dicranopteris linearis (Burm. F.)

10. Diplazium esculentum (Retz.) $S w$.

11. Pityrogramma calomelanos (L.) Link.

12. Parahemionitis cordata (Fraser-Jenk)

13. Arachniodes sledge Fraser-Jenk.

14. Pteris biaurita $L$.

15. Angiopteris helferiana C. Presl

17. Cyathea nilgirensis Holttum

18. Blechnum orientale $L$.

19. Tectaria polymorpha (Wallich. ex Hook.)
Subgroup III includes three species Asplenium obscurum Bl., Pityrogramma calomelanos (L.) Link. and Cyathea nilgirensis Holttum. Group II includes single species Pteris biaurita L. with creeping rhizome. Group III again sub divided into two sub groups. Subgroup I includes two species Tectaria paradoxa (Wallich. ex Hook.) and Dicranopteris linearis (Burm. F.) both possess creeping rhizome. Sub group II includes two species Dryopteris cochleata (Buch. Ham. ex D. Don) and Tectaria polymorpha (Wallich. ex Hook.) having oblong fronds with terrestrial habitat. Sub cluster III consists of a single species
Blechnum orientale L. having dimorphic fronds. Major cluster II sub divided into two sub clusters. Sub cluster I includes two species Pyrrosia porosa T. Moore and Aleuritopteris anceps (Blanf.) Panigrahi having coriaceous texture. Sub cluster II two species Bolbitis semicordata (Bak.) Ching. and Arachniodes sledge Fraser-Jenk both possess creeping rhizome with green stipe. Fern species have distributed based on frond shape, frond type, type of rhizome, habitat, stipe colour, texture, sori position. This variation might have arisen due to the variation in genetic (or structural) origin of each marker, while morphological expression 
(phenotype) is conditioned by the genetic makeup of each species and environmental conditions. Similar observations were made by Barker and Hauk, 2003 in S. dissectum var dissectum and var obliqum. Porash Kumar et al., 2016 in gladiolous and Yi et al., (2018) in geranium. Sexual recombination had been the prime source of genetic variation than asexual reproduction (Kjolner et al., 2006 in Saxifraga). This hereditary variety is probably emerged from contrasts in the DNA content of the progenitor species (Abiya et al., 2014 in Adiantum incisum and Abiya et al., 2016 in Pteris biaurita). The morphological variations were counter confirmed by the genetic variations present in the fern species through ISSR markers. The genetic relationship demonstrated by the molecular markers via DNA fingerprinting shows their nearness and relativity. Ten primers revealed consistent banding pattern and thus revealed diversity within the species.

In conclusion, genetic diversity between fern species has been identified. ISSR markers proved amplification in the selected species thus confirming its genetic distinction strategy. Based on molecular data Parahemionitis cordata (Fraser-Jenk.), Pteris biaurita L. and Blechnum orientale $\mathrm{L}$ branched singly having difference in their morphology.

\section{References}

Abiya, C. D., John, D. B. A. and Samuel, S. A., 2014. Genetic variations of Adiantum incisum Forssk. revealed by ISSR markers in the Western Ghats of Tamil Nadu, India. J. Res. in Biol., 4(8): 1604-1610.

Abiya, C. D., John, D. B. A. and Samuel, S. A., 2016. Heritable variations of Pteris biaurita L. discovered by ISSR markers in the Western Ghats of Tamil Nadu, India. J. Res. in Biol., 6(6): 2078-2084.
Barker, M. S. and Hauk, W. D., 2003. An evaluation of Sceptridium dissectum (Ophioglossaceae) with ISSR markers: implications for Sceptridium systematics, American Fern J., 93(1): 119.

Benjamin, A. and Manickam, V.S., 2007. Medicinal pteridophytes from the Western Ghats. Indian J. Trad. Knowl., 6(4): 611-618.

Caius, J.F., 1935. The medicinal and poisonous ferns of India. J. Bombay Nat. His. Soc., 341-361.

Dixit, R.D., 2000. Conspectus of Pteridophytic diversity in India. Indian Fern J., 17: 77-91.

Doyle, J. J. and Doyle, J. L., 1987. Isolation of plant DNA from fresh tissue. Focus., 12: $13-15$.

Echt, C. S., Erdahl, A. S. and Mccoy, T. G., 1992. Genetic segregation of randomly amplified polymorphic DNA in diploid cultivated alfafa. Genome Res., 35(1): 84-87.

Fraser-jenkins, C.R., 2012. Rare and threatened Pteridophytes of Asia 2. Endangered species of India- the higher IUCN Categories. Bull. Natl. Mus. Nat. Sci. Ser. B, 38(4): 153-181.

Kjolner, S., Sastad, S. M. and Brochmann, C., 2006. Clonality and recombination in the arctic plant Saxifraga cernua. Bot. J. Linn. Soc. 152: 209-217.

Kumar, P., Nareshkumar, Naveenkumar, Chaudhary, C and Sharma, S., 2016. Evaluation of genetic diversity among gladiolus (Gladiolus hybridus hort.) germplasm using ISSR markers. Int. J. Agric. Stat. Sci., 1(12): 277-283.

Lalitha, K. P., Anuradha, G., Pratap, M. and Hameedunnisa begum, 2014a. Genetic diversity revealed in commercial varieties of chrysanthemum using RAPD markers. Electronic J. Pl. Breed., 5(1): 45-51.

Lalitha, K. P., Girwani, A. and Radha, R. K., 
2014b. Genetic diversity in tuberose (Polianthes tuberose L.) using morphological and ISSR markers. Electronic J. Pl. Breed, 5(1): 52-57.

Liu, X. Q., Robert, W. G. and Chen, L. Q., 2007. Genetic variation in the endangered fern Adiantum reniforme var. sinense (Adiantaceae) in China. Ann. Bot. Fennici., 44: 25-32.

Ma, L. Q., Komar, K. M., Tu, C., Zhang, W. H., Cai, Y. and Kennelley, E. D., 2001. A fern that hyper accumulates arsenic a hardy, versatile, fast-growing plant helps to remove arsenic from contaminated soils. Nature, 409: 579579.

Nair, B. K., 1959, Medicinal ferns of India. Bull. Nat. Bot. Gard., Lucknow, 29: 1 36.

Oloyede, F. A. and Odu, E. A., 2012. Survey of ornamental ferns, their morphology and their uses for environmental protection, improvement and management. J. Sci. 14(2): 245-252.

Parashurama, T. R., Deepa, J. and Prakash Kariyajjanavar., 201. Pteridophyte diversity in Mudigere taluk, Central Western Ghats, Karnataka, south India. Int. J. Curr. Res., 8(10): 339-342.

Perrie, L. R., Brownsey, P. J., Lockhart, P. J., and Large, M. F., 2003. Morphological and genetic diversity in the New Zealand fern Polystichum vestitum (Dryopteridaceae), with special reference to the Chatham Islands. New Zealand J. Bot., 41(4): 581-602.

Rashmi, R., 2015. Characterization of gladiolus (Gladiolus hybridus L.) genotypes through morphological and molecular markers. M.Sc. thesis, Univ. Hort. Sci. Bagalkot.

Safeena, S.A., 2013. Comprehensive studies on evaluation of ornamental filler plants, for production of cut foliage and vase life. Ph.D. thesis, Univ. Agric. Sci., GKVK, Bangalore, pp. 156-179.

Yi, Y., Yi, S. W., Qin, T. F. and Li, C. Y., 2018. Using RAPD and ISSR molecular markers to analyze the genetic diversity of rose scented pelargonium populations. Flavour Fragr. J., 33:7581.

\section{How to cite this article:}

Vidyashree, Chandrashekar, S.Y., D.C. Lakshmana Reddy and Lavanya Reddy. 2019. Analysis of Genetic Diversity of Ferns of Western Ghats in Mudigere region of Karnataka based on ISSR Markers. Int.J.Curr.Microbiol.App.Sci. 8(02): 1372-1378.

doi: https://doi.org/10.20546/ijcmas.2019.802.161 